\title{
Female Translation Students' Knowledge and Use of Online Dictionaries and Terminology Data Banks: A Case Study
}

\author{
Nadia Sabbah \\ Department of English and Translation, College of Humanities, Prince Sultan University, \\ Riyadh, Saudi Arabia \\ Reem Alsalem \\ Department of English Language and Translation, College of Languages and Translation, \\ King Saud University, Riyadh, Saudi Arabia
}

\begin{abstract}
This study aims to determine whether translation students at an undergraduate translation program have sufficient awareness of the availability and usability of online vocabulary and terminology search tools that can be of valid assistance to a translator. The study surveyed 50 female translation students of the Translation Program at Prince Sultan University, Saudi Arabia. The survey consisted of questions about knowledge and use patterns and included texts for translating between English and Arabic. Results show that although the students know and use a variety of online resources, they still lack in awareness of some of the very useful ones, and a small minority of the students does not use monolingual dictionaries at all. Analysis of the students' translations of selected terms reveals that availability of excellent online resources is not enough to prevent mistranslations if the students cannot select the right equivalent. The study has implications for lexicographers about the dictionary features most frequently used by translators-to-be. It also provides pedagogical tips for translator trainers who should guide their students to making use of the full potential of online dictionaries and term banks in order to achieve better translation outcomes.
\end{abstract}

Key words: CAT tools, online dictionaries, term base, terminology data banks, translation

Cite as: Sabbah, N., \& Alsalem, R. (2018). Female Translation Students' Knowledge and Use of Online Dictionaries and Terminology Data Banks: A Case Study. Arab World English Journal for Translation \& Literary Studies, 2 (2). DOI: http://dx.doi.org/10.24093/awejtls/vol2no2.6 